\title{
J Trevor Williams (1938-2015): IBPGR director and genetic conservation pioneer
}

\author{
M. T. Jackson
}

(C) Springer Science+Business Media Dordrecht 2015

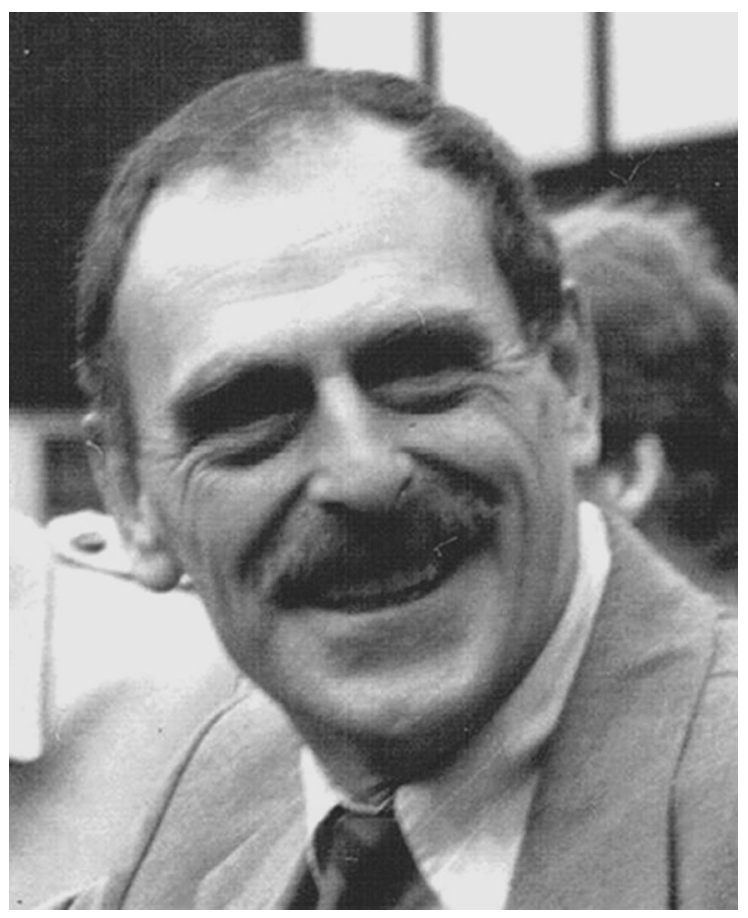

John Trevor Williams (always known as Trevor), who was Executive Secretary and first Director of the International Board for Plant Genetic Resources

M. T. Jackson ( $₫)$

Bromsgrove, Worcestershire, UK

e-mail: grace@mike.jacksonmail.org
(IBPGR) between 1978 and 1990, passed away at the age of 76 on 30 March 2015 at his home in Cheshire, UK after a long respiratory illness.

One legacy of Trevor's contribution to the conservation of plant genetic resources can be found deep beneath the Arctic permafrost on the island of Spitsbergen, where millions of seeds of crop varieties and wild species-many collected through the efforts of IBPGR in the 1970s and 1980s-are in backup storage in the Svalbard Global Seed Vault (SGSV), popularly known as the 'Doomsday Vault'. Opened 7 years ago, the SGSV is one major achievement of a plan set in motion three decades earlier by IBPGR to establish an international network of regional and national genebanks. The proposal to store backup samples of international genebank collections under the permafrost was first developed by IBPGR in 1988 (IBPGR 1990, p. 10), building on the experience of the Nordic Genebank that had already used an abandoned coal mine on Svalbard for the same purpose.

\section{A passion for natural history}

Born in Thingwall, Cheshire in June 1938, Trevor developed a life-long passion for natural history, particularly botany, from an early age. He learned to name all the local flowers when evacuated to the Isle of Man during the Second World War after the family home was bomb damaged. 
After high school, he was awarded an Open Exhibition to Selwyn College, Cambridge University in 1956 to study medicine. But after just one year he transferred to botany having been advised that 'too many medical doctors were being trained'. He graduated in botany in 1959. As would transpire later in his career, medicine's loss was genetic conservation's gain!

After Cambridge he joined eminent plant ecologist and population biologist Professor John Harper in the Department of Agricultural Botany at the University of Wales, Bangor (now Bangor University), completing his $\mathrm{PhD}$ in 1962 on the weed biology of Chenopodium (Williams 1962). Trevor was a coauthor of one of the most significant papers published from the Harper laboratory (Harper et al. 1965). He then spent 18 months teaching at Goldsmiths College, University of London, before taking a research fellowship in the Geobotanical Institute at ETH Zurich, under the supervision of phytogeographer Heinz Ellenberg. In 1968 he was awarded the Dr sci nat degree for his research on the nitrogen relations and ecology of wet fertilized meadows in Switzerland, southern Germany, and France (Williams 1968). On his return to the UK, he was appointed lecturer in biology at Lanchester Polytechnic (now Coventry University).

$\mathrm{He}$ was elected to the Council of the British Ecological Society in 1970 for 4 years, and served the Botanical Society of the British Isles, Warwickshire Nature Conservation, and the Birmingham Natural History Society in various capacities. He was a Fellow of the Linnean Society of London.

\section{Genetic resources at Birmingham}

In September 1969, Professor Jack Hawkes, internationally-renowned genetic resources scientist and potato expert, recruited Trevor to join the Department of Botany at the University of Birmingham. He was appointed Lecturer and Course Tutor for the graduate MSc course on Conservation and Utilization of Plant Genetic Resources that saw its first intake of four students from Brazil, Canada and the UK that same month.

While at the University of Birmingham, Trevor initiated genetic resources research on the genus Beta (Ford-Lloyd and Williams 1975) and this included participation in collecting missions, particularly to Turkey in 1972. In fact, the collections became the forerunners of subsequent European and World Beta germplasm collections that are of current importance. The collecting experience also served Trevor in good stead for directing genetic resources collecting of many other crops under the auspices of IBPGR. One of the other outcomes of these collecting activities was to provide a taxonomic footing for Beta conservation. Trevor jointly named a new genus of beet, which at the time was perhaps controversial (Williams and Ford Lloyd 1974). It was subsequently shown to be not only a bold but a scientifically correct move as many molecular genetic assessments have confirmed.

\section{The move to Rome}

However, in 1976, Trevor was seconded for 2 years to IBPGR as Genetic Resources Officer/Senior Genetic Resources Officer in the Crop Ecology and Genetic Resources Unit of the Food and Agriculture Organization (FAO) in Rome, home to IBPGR since its foundation in 1974. He resigned from the University of Birmingham in June 1978 when he was appointed Executive Secretary of IBPGR.

Funded by the Consultative Group on International Agricultural Research (CGIAR), IBPGR's mandate was to advance the conservation and use of plant genetic resources for food and agriculture. After all, this was just a decade or so after the launch of the 'Green Revolution', and many traditional crop varieties were thought to be in danger of extinction as farmers adopted higher-yielding varieties in their stead. This eventuality had been forecast in the 1960s and the need for exploration and conservation was highlighted in the groundbreaking publication edited by Frankel and Bennett (1970). Among the proposed solutions was placing seeds in genebanks for long-term conservation. But in 1974, when IBPGR began operations, there were only a few genebanks or ex situ collections across the globe where germplasm could be safely stored. Furthermore, few germplasm collecting missions had been made to systematically collect germplasm from farmers' fields before it was lost forever.

Under Trevor's dynamic leadership at IBPGR, many countries were helped to set up genetic resources programmes where none had previously existed. In 
turn, as genetic resources conservation became widely recognized as an important component of enhanced food security, demands for training and research on different conservation approaches increased, as did demand for technical information, and assistance (both financial and technical) to collect and conserve crop genetic resources. IBPGR sponsored over 800 collecting trips in 100 or more countries, with the result that almost 211,000 germplasm samples were placed in genebanks around the world. This was a prudent move as subsequent events have borne out. IBPGR hired staff (several were Birmingham graduates) to help collect germplasm, even from countries where there was a significant threat of conflict or civil disturbance. Some of these countries are now virtually inaccessible and unsafe.

In terms of training, the launch of the Birmingham MSc course in 1969 could not have been better timed. By the mid-1970s, IBPGR stepped into sponsor many scholars from developing countries to study the theory and practice of plant genetic conservation and use at Birmingham, and provided practical training at a number of genebanks around the world. IBPGR also provided financial and staffing support to the University of Birmingham to increase its capacity to accommodate the growing demand for student places.

Early on, IBPGR promoted international collaboration between crop experts to form crop advisory committees and working groups to develop collecting and conservation guidelines, especially for difficult to conserve germplasm (Withers and Williams 1982). IBPGR published descriptor lists for 73 crops in its Genetic Resources of Crops series, as well as ecogeographic studies of crop genepools, practical manuals, and handbooks in several languages. The application of information technology and databases to manage germplasm collections was another initiative that prospered under Trevor's direction. IBPGR regional programmes in Latin America, South and Southeast Asia, and in West and East Africa provided its important outreach capacity to national germplasm systems. IBPGR also established a Seed Handling Unit at Kew-Wakehurst Place in 1988 (followed, in subsequent years, by units at the National University of Singapore and in Turrialba, Costa Rica) to process seeds from collecting missions sponsored by IBPGR, and prepare them for long-term conservation in a designated genebank.

Trevor championed development of a research capability within IBPGR, something that did not sit easily under the FAO umbrella. By the end of the 1980s, however, staff had been recruited and research networks initiated on genetic diversity, seed physiology, germplasm health, and in vitro conservation for crops that cannot be stored as seeds, among others, in partnership with national scientists around the world. One important network was the European Cooperative Programme for Plant Genetic Resources (ECP/GR) and Trevor served from 1985 as its Executive Secretary.

By the beginning of 1990, facing challenges such as the increasingly politicized germplasm sharing environment, the controversies of emerging biotechnology, and relations with the NGO community (which Trevor, to give him credit, had addressed with the appointment of a public awareness professional, the first in the CGIAR) the IBPGR Board of Trustees decided on a change of leadership. Tensions had escalated between IBPGR and FAO, exacerbated no doubt by the fact that Trevor was serving as both Director of IBPGR and Head of FAO's Crop Genetic Resources Centre, which led to an uneasy relationship between the two organizations.

In February 1990, Trevor stepped down as Director. By then, however, his legacy was firmly established. There were hundreds of genebanks or ex situ collections around the world, as well as national capacity and technical expertise to manage these valuable resources. Furthermore IBPGR was a very different organization from that set up in 1974. Its own research capability had grown significantly, and in 1991 it became the International Plant Genetic Resources Institute (IPGRI) independent of FAO, and from 2006, Bioversity International. As a former colleague comments, 'Trevor enjoyed a risk and it was his ability to take a chance that I'm convinced enabled IBPGR to grow and for many of us to have had the careers or experiences that we did have. There would never have been an IPGRI, Bioversity [International] or [Global Crop Diversity] Trust if it wasn't for Trevor.'

During his IBPGR tenure and afterwards, Trevor authored or contributed to some important publications on the issues and challenges around plant genetic resources, including environmental concerns, climate change, food security, and future directions, among others (Plucknett et al. 1983; Holden and Williams 1984; Plucknett et al. 1987; Williams 1988; Williams 1990; Cohen et al. 1991; Williams 1991). In his early writing, Trevor discussed the role of in situ 
conservation of crop wild relatives (Ingram and Williams 1984), and later on, models for in situ conservation (Maxted et al. 1997), and the link between ex situ and in situ conservation in a cuttingedge commentary in Diversity (Williams 1993).

\section{The post-IBPGR years: bamboo, rattan and underutilized crops}

Leaving IBPGR, Trevor moved to Washington, DC to become Director of the International Fund for Agricultural Research (IFAR) and IBPGR-sponsored Tropical Trees Program (TTP). He called the programme 'essential' as 'millions of disadvantaged people have relied on these crucial plants' (Smith et al. 1992), and through the TTP became a scientific and policy adviser to the Bamboo and Rattan Research Network in Asia, initially an informal network supported by Canada's International Research Development Centre (IDRC). In 1991, IDRC asked Trevor to lead a study team to review bamboo and rattan research needs for the next decade. He also formed a working group on genetic resources, under the auspices of IPGRI. He co-authored a pivotal report to identify priority species of bamboo and rattan (Rao et al. 1998) that recognized their value for local communities, and society at large. When the International Network for Bamboo and Rattan (INBAR) became the first intergovernmental organization to be headquartered in Beijing in 1997, Trevor was at the signing ceremony in the Great Hall of the People and received recognition for his important advisory role during INBAR's formative years.

Trevor's genetic resources interests expanded to encompass underutilized crops. He helped found the International Centre for Underutilized Crops in Southampton, UK, joining its Board and was Chair from 1998 to 2005. This interest in underutilized crops led to several significant publications (Williams 1995b; Padulosi et al. 2002; Sidibe and Williams 2002; Williams and Haq 2002).

While in Washington, he frequently contributed to the genetic resources news magazine Diversity that initially covered issues involving the US germplasm programme. During the 1980s and 1990s it became clear that genetic conservation, and access to and use of genetic resources were growing global issues, and Diversity had to change its focus. Trevor soon became an indispensable friend and mentor to Diversity staff, 'educating them in key aspects of germplasm science and politics' particularly as they related to the international arena. In 1993, the Diversity Board of Directors elected Trevor to the Board, a role he had been providing informally for years. In what was a 'herculean and indispensable' effort, he contributed to Diversity's first issue devoted to a specific region of the world: Latin America. His ideas, contacts with potential authors, and assistance with editing made the project a truly landmark project. Other special regional issues on the Mediterranean region appeared in 1995 (for which Trevor wrote the foreword, Williams 1995a) and 1996 (India and South Asia). As the former editor of Diversity recalls about the issue on Mediterranean genetic resources, 'His contacts with and oversight of the many contributors who were operating under sometimes-difficult political circumstances literally served as the bedrock of the project. One of the things I found most compelling about the project was its focus on the relationship between peace and genetic resources, with one section being devoted entirely to Biodiversity and the Peace Process. Looked at today, this may seem naïve, but many of these brave scientists and policymakers saw only a Fertile Crescent without borders'.

\section{Recognition by peers}

Among his awards were an Honorary Professorship at the University of Birmingham in 1984; the Jubilee Medal (1977) from the National Agrarian University, Lima, Peru; a Certificate of Honour for Scientific Excellence from the Royal Government of Thailand (1984); and Certificate of Commendation, Argentina Agricultural Veterinary Academy for services to maize breeding in Latin America (also 1984). In 1984-1986, he served as the Chair of the International Center Directors Committee of the CGIAR. After the 1984 Indian Ocean tsunami he was asked by the UN to chair an intergovernmental meeting in Bangkok to discuss aid for affected agricultural lands, and technical solutions for recovery of soils from salination.

Nicknamed 'The Boxer' by Birmingham students for his stocky stature and prominent eyebrows, and 'Little General' among his genetic resources colleagues, Trevor was a whirlwind of energy, an inspirational teacher and mentor, who encouraged 
many students to follow a career in genetic conservation. Many went on to become leaders of their own national genetic resources programmes.

His 'crusty' exterior disguised a generous heart. 'Trevor was an outstanding scientist with a broad appreciation and knowledge about botany and genetics and how they could be applied to crop development', remembers a former IBPGR colleague. 'He guided the new institute with strong scientific and political leadership building a strong and dedicated team who made significant contributions to genetic resources collection and genebank management'. And another confirmed Trevor's support. 'I loved those early years of IBPGR. No-one had secure jobs and noone cared. At least not those of us in the field. We were collecting and helping to build national capacity in collecting and conservation, and helping to build the science of PGR - we all felt like pioneers. Trevor made us feel like that ...'

Trevor had a deep Christian faith, and a special devotion to St George, the patron saint of England. At the time of his death he was working on a definitive account of the plants in the Bible. He is survived by his elder sister, the Reverend Wendy Williams. He was unmarried.

\section{References}

Cohen JI, Williams JT, Plucknett DL, Shands H (1991) Ex situ conservation of plant genetic resources: global development and environmental concerns. Science 253:866-872

Ford-Lloyd BV, Williams JT (1975) A revision of Beta Section Vulgares (Chenopodiaceae), with new light on the origin of cultivated beets. Bot J Linn Soc 71:89-102

Frankel OH, Bennett E (eds) (1970) Genetic Resources in Plants - their Exploration and Conservation. IBP Handbook No 11. Blackwell Scientific Publications, Oxford and Edinburgh

Harper JL, Williams JT, Sagar GR (1965) The behaviour of seed in soil. 1. The heterogeneity of soil surfaces and its role in determining the establishment of plants from seed. J Ecol 53:273-286

Holden JHW, Williams JT (eds) (1984) Crop genetic resources: conservation and evaluation. George Allen \& Unwin, London

IBPGR (1990) Annual report 1990. Italy, Rome

Ingram GB, Williams JT (1984) In situ conservation of wild relatives of crops. In: Holden JHW, Williams JT (eds) Crop genetic resources: conservation and evaluation. George Allen \& Unwin, London, pp 163-179

Maxted N, Hawkes JG, Ford-Lloyd BV, Williams JT (1997) A practical model for in situ genetic conservation. In: Maxted N, Ford-Lloyd BV, Hawkes JG (eds) Plant genetic conservation-the In Situ Approach. Chapman \& Hall, London, pp 339-367

Padulosi S, Hodgkin T, Williams JT, Haq N (2002) Underutilized crops: trends, challenges and opportunities in the $21 \mathrm{st}$ century. In: Engels JMM, Rao VR, Brown AHD, Jackson MT (eds) Managing plant genetic diversity. CABI, Wallingford, Oxon, pp 323-338

Plucknett DL, Smith NJH, Williams JT, Anishetty NM (1983) Crop germplasm conservation and developing countries. Science 220:163-169

Plucknett DL, Smith NJH, Williams JT, Anishetty NM (1987) Genebanks and the World's Food. Princeton University Press, Princeton

Rao AN, Ramanatha Rao V, Williams JT (eds) (1998) Priority species of bamboo and rattan. IPGRI and INBAR, IPGRIAPO, Serdang, Malaysia

Sidibe M, Williams JT (2002) Baobab, Adansonia digitata. International Centre for Underutilized Crops, Southampton, UK

Smith NJH, Williams JT, Plucknett DL, Talbot JP (1992) Tropical forests and their crops. Comstock Publishing Associates (Cornell University Press), Ithaca and London

Williams JT (1962) Studies on the biology of weeds with special reference to the genus Chenopodium $\mathrm{L}$. $\mathrm{PhD}$ thesis, University of Wales

Williams JT (1968) The nitrogen relations and other ecological investigations on wet fertilized meadows. Diss. Naturwiss, ETH Zurich

Williams JT (1988) Identifying and protecting the origins of our food plants. In: Wilson EO (ed) Biodiversity. National Academy Press, Washington, DC, pp 240-247

Williams JT (1990) The implications of climatic changes for plant genetic conservation strategies. In: Jackson M, FordLloyd BV, Parry ML (eds) Climatic change and plant genetic resources. Belhaven Press, London and New York, pp 167-178

Williams JT (1991) Plant genetic resources: some new directions. Adv Agron 45:61-91

Williams JT (1993) In review: genetics and conservation of rare plants. Diversity 9(1\&2):84

Williams JT (1995a) Mediterranean genetic resources and the human perspective: past and present. Diversity 11(1\&2):ii-iii

Williams JT (ed) (1995b) Cereals and Pseudocereals. Chapman and Hall, London

Williams JT, Ford Lloyd BV (1974) The systematics of the Chenopodiaceae. Taxon 23:353-354

Williams JT, Haq N (2002) Global research on underutilized crops. An assessment of current activities and prospects for enhanced cooperation, International Centre for Underutilized Crops, Southampton

Withers LA, Williams JT (eds) (1982) Crop genetic resourcesthe conservation of difficult material. IUBS/IBPGR, Paris 